\title{
Do BRICS Countries Have Similar Trade Integration Patterns?
}

\author{
Ehsan Rasoulinezhad \\ University of Tehran, Tehran, Iran \\ Farkhondeh Jabalameli \\ University of Tehran, Tehran, Iran
}

\begin{abstract}
This study explores the similarities of trade integrations in the BRICS member countries. Using time series data from 2001 to 2015 and employing the Panel-Gravity trade model approach, we utilized the separate disaggregated trade data of manufactured goods and raw materials of each BRICS member with United Nations-defined regional groups: the African group, the Asia Pacific group, the Eastern European group, the Latin American and Caribbean group, and the Western European. The analysis results revealed that Russia's manufactured goods and raw material trade integration based on the HeckscherOhlin framework with these five regional groups is not similar to that of other BRICS members following the Linder hypothesis. Furthermore, the dominance of China in total trade flows of BRICS has made the Chinese Yuan's effects on trade with partners from different groups stronger than other BRICS members' national currencies impacts. Geographical distance as a proxy for transportation cost has a weaker negative effect on the manufactured goods and raw materials trade patterns of China and India than it does on other countries, creating dissimilarity in the trade patterns of BRICS countries.
\end{abstract}

\footnotetext{
* Corresponding Author: Ehsan Rasoulinezhad; Postdoctoral fellow, Faculty of Economics, University of Tehran, Tehran, Iran, Tel: +989215065289, E-mail: erasolinejad@gmail.com

Co-author: Farkhondeh Jabalameli; Associate Professor, Faculty of Economics, University of Tehran,Tehran, Iran, Email: fameli@, ut.ac.ir 
JEL classifications: C21, C23, F10, F14

Keywords: Gravity Model, Bilateral Trade, Panel Data

\section{Introduction}

With regards to trade integration, a challenge is that how we can measure or analyze the trade integration pattern between countries. One of the most popular instrument is the gravity model of trade, which was first introduced by Tinbergen (1962) and Poyhonen (1963) on the basis of the notion that bilateral trade flowing between two countries directly depends on national incomes and indirectly links with bilateral distance (Rasoulinezhad 2016). This pattern of relationships among bilateral trade, economic size, and distance could help researchers analyze bilateral or multilateral trade integration between two or more countries.

This study attempts to analyze the bilateral trade integration patterns of BRICS ${ }^{1}$ member countries over the period of 2001 2015 by using a panel data approach under gravity model foundation. The main motivations of choosing BRICS countries in our study are as follows.

First of all, the contribution of BRICS countries to world economic growth during the past decade is known to have exceeded nearly 50\%, and these countries' economic growth rates will be higher than those of developed nations and other emerging economies by 2030 (Ayhan Kose and Ozturk 2014). The following figure illustrates the Gross Domestic product (GDP) growth rate of BRICS compared to developed nations from 2001 to 2015.

As shown in Figure 1, among BRICS economies, China and India have experienced relatively higher GDP growth from 2001 to 2015. The Russian Federation had a significant negative GDP growth rate during 2009 2010, affected by the global economic recession and the western sanctions in recent years. South Africa has also experienced a smooth GDP growth rate of $0 \sim 5 \%$, except in 2010 — when the global economic recession harshly affected its labor market in which one-third of the labor force was unemployed.

\footnotetext{
${ }^{1}$ Although BRIC was coined in 2001 by Goldman Sachs and changed to BRICS after the induction of South Africa in 2010, we consider the BRICS for the period of our research from 2001 2015.
} 
Another BRICS member, Brazil, faced numerous fluctuations. For example, Brazil has experienced various economic events, such as the most overvalued currency in the world in 2009 and a large account deficit in 2014.

Figure 1. GDP economic growth in BRICS economies

(US dollars)

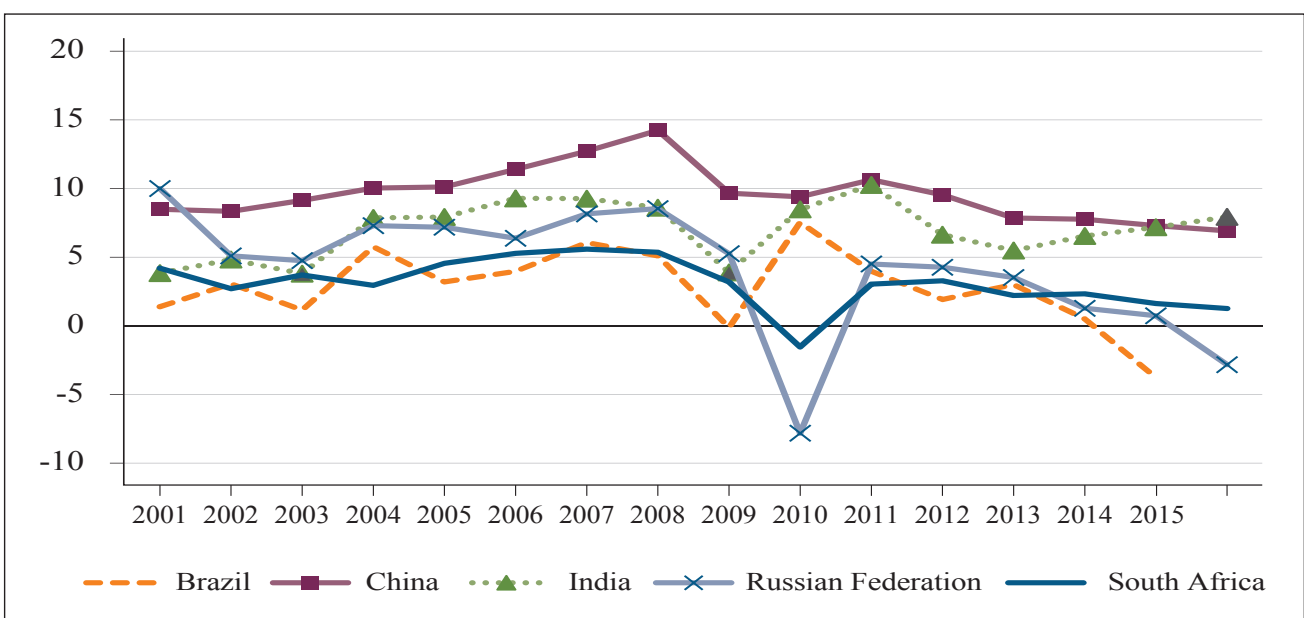

(Note) The figure illustrates the trends of GDP economic growth in five BRICS member countries (Source) World Bank database

Second, BRICS has a significant role in the global trade flows. Its contribution to the global trade turnover has approximately tripled over the last two decades which proves the increased magnitude of BRICS in the global trade flows. Based on the Trade Map data, the BRICS' imports value has increased from 417 billion US dollars in 2001 to over 2,339 billion US dollars in 2016, while the BRICS's exports value has boosted up from 494 billion US dollars in 2001 to nearly 2,902 billion US dollars in 2016. As the global contribution in import flows, the BRICS's contribution to the global imports value has increased from $2.21 \%$ to $14.5 \%$ in 2001 and 2016, respectively. In the case of BRICS's contribution to the global export flows, it can be expressed that its share has moved from $8.06 \%$ in 2001 to over $18.1 \%$ in 2016 . The raised contributions of BRICS in the global flows are an evidence of increased role of the international trade. Table 1 represents trade flows of BRICS with different regions between 2001 and 2016. 


\section{Table 1. Trade flows of BRICS with different regions}

(2001 2016, Million US dollars)

\begin{tabular}{|l|l|c|c|c|c|c|}
\hline & & $\mathbf{2 0 0 1}$ & $\mathbf{2 0 0 5}$ & $\mathbf{2 0 1 0}$ & $\mathbf{2 0 1 5}$ & $\mathbf{2 0 1 6}$ \\
\hline \multirow{4}{*}{ Africa } & Import from BRICS & 15,926 & 41,045 & 115,182 & 167,714 & 152,063 \\
\cline { 2 - 8 } & Export into BRICS & 11,690 & 36,136 & 120,217 & 122,368 & 95,687 \\
\hline \multirow{4}{*}{ America } & Import from BRICS & 117,022 & 291,161 & 527,716 & 709,872 & 665,526 \\
\cline { 2 - 8 } & Export into BRICS & 75,066 & 136,668 & 333,938 & 409,301 & 374,117 \\
\hline \multirow{4}{*}{ Asia } & Import from BRICS & 195,502 & 503,094 & $1,043,463$ & $1,474,186$ & $1,366,585$ \\
\cline { 2 - 8 } & Export into BRICS & 189,402 & 555,312 & $1,210,608$ & $1,341,769$ & $1,138,583$ \\
\hline \multirow{3}{*}{ Europe } & Import from BRICS & 156,588 & 414,466 & 699,423 & 669,527 & 653,610 \\
\cline { 2 - 7 } & Export into BRICS & 117,486 & 233,422 & 483,891 & 520,199 & 497,650 \\
\hline
\end{tabular}

(Note) The table represents the value of exports into and imports in related to BRICS (Source) Authors' compilation from the Trade Map database

As shown in Table 1, export and import flows of BRICS with the regions, i.e. Africa, America, Asia and Europe, have been increased over this period. For BRICS's imports, Asia and Europe are the largest exporters to these five economies in 2016, while America and Africa have the smallest contributions in this year. Meawhile, for BRICS's exports between 2001 2016, Asia and Europe are the top importers from BRICS, while two rest regions, America and Africa, are the smallest importers from them. Hence, it can be concluded that Asia and Europe are the top regional trade partners for BRICS economies.

Although the trade flows of BRICS members has drawn some attention from researchers - Yavuz Cakir and Kabundi (2013), Yin (2014), Izotov (2007), Nayyar Rahman (2016), Bezuidenhout and Claassen (2013), Clus-Rossouw et al. (2015) Caporale et al. (2015), and Fung et al. (2015) — we do not find a study that analyzes the similarity in trade integration patterns of BRICS members using a gravity model. This study will fill the gap.

The remainder of this paper is structured as follows: Section II provides a brief literature view; Section III discusses data and econometric model; Section IV presents the research results; and finally, section $\mathrm{V}$ concludes with directions for further research. 


\section{Literature Review}

The literature can be divided into three main strands: (i) consideration of trade integration between nations; (ii) applying the gravity model to explore trade integration patterns; (iii) investigation BRICS' bilateral or multilateral trade patterns by using the gravity trade model.

The first strand mainly concentrates on the importance of trade integration between nations. Surugiu and Surugiu (2015) emphasized that trade integration creates a new growth opportunities for companies which leads to a wider range of products and services for consumers. Furthermore, a result of increased trade integration is less responsive to the exchange rate. Gust, Leduc, and Vigfusson (2010) developed an open economy Dynamic General Equilibrium (DGE) model and find that with increase trade integration exporters have become more responsive to the prices of their competitiors. Kraay and Ventura (2002) showed that trade integration increases the volatility of the trade balance and amplifies the risk of trade sector. Moreover, Hallett and Pisciatelli (2002) showed that different nations provide dissimilar trade integration patterns. The results revealed that large and stable economies with integrated structures are likely to diverge, while trade integration in smaller economies leads to economic convergence. In consistent with this study, Palmer and Elliott (2003) proved the same result for developing countries. It revealed that four Latin American and Caribbean economic groups have different trade integration patterns due to the specifications of extra-group markets.

The second strand considered the gravity trade for analyzing trade integration patterns. Jakab, Kovacs, and Oszlay (2001) investigated the development of trade in the Czech Republic, Hungary and Poland applying the gravity model. The results revealed that the differences in the speed of trade convergence among the three nations based on the product-structure of exports and the impacts of Foreign Direct Investment (FDI). Carrilo-Tudela and Li (2004) applied the gravity trade model to analyze the impacts of the Andean Community and Mercosur on intra-regional and intra-industrial trade integration for the period 1980 1997. They found that Mercosur preferencial trade agreements has a positive impact on the capital-intensive subcategory of the reference products. Chen and Novy (2011) used a micro-founded measure that accounts for corss-industry heterogeneity in a gravity trade framework. They found that substantial technical barriers are the most notable barriers which shape the integration patterns between countries. Rasoulinezhad (2016) explored the Iran-Russia trade pattern under 
oil price shocks and sanctions effects by using the gravity trade model. The estimation results depicted that sanctions affect the Iran-Russia trade pattern more than global oil price shocks. Rasoulinezhad (2017) employed a panel-gravity model to study the bilateral trade patterns between China and 13 OPEC economies over 1998 2014. The findings showed that the trade pattern relies on the Heckscher-Ohlin (H-O) pattern. Nasre Esfahani and Rasoulinezhad (2017) analysed trade integration pattern of Iran under sanctions by using the gravity theory. They explored the trade integration pattern of Asianization and de-Europeanization of Iran under sanctions' circumstances. It concludes that the gravity trade model fits the data and can explain the trade integration pattern in a particular structure.

Lastly, a combined approach of the above two strands has emerged in the recent literature which enables to conduct the trade patterns of BRICS applying the gravity model.

In an empirical study, Fadaee, Abolhasani, and Shaygani (2013) attempted to test the Linder theory in BRICS economies by using the generalized gravity model for the period 2001 2013. They concluded that using a free-floating exchange rate arrangement had no significant effect on bilateral trade in the selected countries. Furthermore, the managed floating exchange rate arrangement significantly and negatively affected bilateral trade, whereas pegged and crawling pegged affected it positively.

Kumar Mishra et al. (2015) investigated India-BRICS trade flows using a gravity model during 1990 2010 and found that a positive relationship exists between the Gross National Product (GNP) and per capita GNP of the nation and its trade volume. Furthermore, transport costs play a negative role in influencing foreign trade among BRICS nations. Kundu (2015) concentrated on the bilateral trade balance of Bangladesh with BRICS countries through a static panel-gravity data analysis during 1991 2013. The research found significant effects of all of the factors (relative GDP, relative per capita gross national income, real exchange rate, import-weighted distance) on the concerned bilateral trade balance. Shaygani et al. (2015) represented a study to find the effects of imposed exchange rate arrangements on the trade volume of BRICS countries between 2001 and 2013 using the generalized gravity model. The results showed that imposing pegged exchange rate arrangements improves bilateral trade toward exports, and inversely, free-floating arrangements improved bilateral trade toward imports. Shah Zainal Abidin et al. (2016) considered the Malaysia-BRICS trade linkages through a gravity model approach for 1980 2015. The findings revealed that the negative effects of distance and corruption on bilateral trade between Malaysia and BRICS economies. 
Furthermore, the inflation and exchange rates of Malaysia and BRICS countries were found to have no effect on the bilateral trade between these nations. In another empirical study, Nayyar Rahman (2016) investigated the role of the World Trade Organization (WTO) in promoting the merchandise trade of BRICS during 1995 2014 using a gravity model, concluding that the WTO accession positively impacted on enhancing trade flows in BRICS economies. Zharikov et al. (2016) focused on an econometric estimation of bilateral transboundary trade between two BRICS members - Russia and Chinausing a gravity model. The estimation results showed that the coefficients for the main variables of the model are relevant, thus proving its theoretical significance. De MelloSampayo (2017) compared two competing-destination formulations of the gravity model as applied to trade in intermediates in the cases of BRICS members. The findings revealed that firms may purchase some of their inputs from other firms by paying the required transport costs.

Review of the previous literature leads to the conclusion that no empirical studies have applied a gravity model to compare the manufactured-based trade pattern and raw material-based trade pattern of BRICS countries with different regions. The present empirical study is the first to focus on a comparison of trade integration patterns of BRICS countries through a gravity trade approach to fill the gap. 


\section{Data and Model}

This study uses annual time series data for the period 2001 2015 to analyze trade integration patterns between the BRICS member countries and their trade partners comprising the 2014 United Nations (UN) Regional Groups: ${ }^{2}$

- Group I: The African group comprising 53 member states

- Group II: The Asia Pacific group comprising 21 member states

- Group III: The Eastern European group comprising 22 member states

- Group IV: The Latin American and Caribbean group comprising 32 member states

- Group V: The Western European and Others group comprising 28 member states plus 1 member state as an observer

To analyze trade integration pattern of the BRICS member countries with these five UN's regions, we use a modified gravity model due to previous models suffered from the omitted variable bias in the model. In this study, to circumvent this problem, we employ a gravity model framework by including various proxies. According to the trade structures of BRICS economies in Trade Map database, manufacturing goods ${ }^{3}$ and raw materials ${ }^{4}$ are the most imported and exported products in the BRICS's trade structure. ${ }^{5}$ Hence, we employ the disaggregated trade data of raw materials and manufactured goods as a dependent variable. Using the disaggregated trade data helps us to cover up the problem of zero trade flows in the gravity trade model. Our independent variables include GDP, difference in income, geographical distance, trade openness, bilateral exchange rate and multilateral resistance term. Data were collected for 2001 2015. World Bank $^{6}$ data that was used to calculate trade openness (in \%) and GDP (thousands US dollars). Data for geographical distance (kilometers) between capital cities were

\footnotetext{
The countries in each of these groups can be checked through the following link. Furthermore, we removed the BRICS countries from the related groups. https:/www.un.org/depts/DGACM/RegionalGroups.shtml

3 Included Harmonized System (HS) codes of 84, 85, 87 and 88

${ }^{4}$ Included Harmonized System (HS) codes of 27 and 72

5 In case of BRICS's exports, manufactured goods has a share of $36.5 \%$ of total BRICS's exports in 2016, while raw materials contributes to $26.8 \%$ of total BRICS's exports in 2016. In regards to BRICS's imports, manufactured goods and raw materials have contributions of $37.6 \%$ and $13.8 \%$ in 2016 , respectively.

${ }^{6} \mathrm{http}$ //data.worldbank.org/
} 
collected from CEPII ${ }^{7}$. Trade Map $^{8}$ was the source of the data on disaggregated trade flows (thousands US dollars) of manufactured goods and raw materials.

Based on the dependent and independent variables, our econometric gravity model can be specified as follows:

Model A:

$$
\begin{aligned}
\ln \left(T M A N_{i j t}\right)= & \delta_{1}+\delta_{2} \ln \left(Y_{i t} Y_{j t}\right)+\delta_{3} \ln \left(D Y P_{i j t}\right)+\delta_{4} \ln E X_{i j t} \\
& +\delta_{5} \ln T O_{i j t}+\delta_{6} \ln R E M_{i j t}+\varepsilon_{i j t}
\end{aligned}
$$

Model B:

$$
\begin{aligned}
\ln \left(T R A W_{i j t}\right)= & \delta_{1}+\delta_{2} \ln \left(Y_{i t} Y_{j t}\right)+\delta_{3} \ln \left(D Y P_{i j t}\right)+\delta_{4} \ln E X_{i j t} \\
& +\delta_{4} \ln T O_{i j t}+\delta_{5} \ln R E M_{i j t}+\varepsilon_{i j t}
\end{aligned}
$$

where $T M A N_{i j t}$ and $T R A W_{i j t}$ are disaggregated trade flows between each member of BRICS (country $i$ ) and a trading partner (country $j$ ) in manufactured goods and raw materials, respectively; $i$ represents each member of BRICS (Brazil, Russia, India, China, and South Africa); $j$ indicates a trading partner; and $t=2001,2002, \ldots, 2015$ refers to the period. $Y_{i t} Y_{j t}$ expresses joint GDP (economic size) of country $i$ and trading partner $j$ at time $t$; and $D Y P_{i j t}$ is the difference between the incomes of country $i$ and trading partner $j$. The coefficient of this variable proves the existence of the Linder's hypothesis or the Heckscher-Ohlin (H-O) trade hypothesis. Furthermore, $E X_{i j t}$ refers to the bilateral exchange rate of each BRICS member (country $i$ ) to trading partner $j$. $T O_{i j t}$ denotes the trade openness, respectively. REM $M_{i j t}$ represents the Multilateral Resistance Term (MRT), which was first introduced by Anderson and Wincoop (2003). Following Baier and Bergstrand (2007), we calculated this variable as the GDP weighted average of the distance from trading partners. Finally, $D I S_{i j t}$ shows the geographical distance between capital cities in each BRICS member (country $i$ ) and trading partner $j$.

${ }^{7}$ http://www.cepii.fr/CEPII/en/

${ }^{8} \mathrm{http}: / /$ www.trademap.org 
Considering the literature on the gravity trade model, the expected signs of the variable coefficients in our models are reported in Table 2.

\section{Table 2. Expected signs of the variables}

\begin{tabular}{|l|c|c|c|}
\hline \multicolumn{1}{|c|}{ Variable } & Symbol & Type & Expected sign \\
\hline Joint GDP & $Y_{i t} Y_{j t}$ & Time-variant & + \\
\hline Difference in income & $D Y P_{i j t}$ & Time-variant & Ambiguous \\
\hline The Trade Openness & $T O_{i j t}$ & Time-variant & + \\
\hline Bilateral exchange rate & $E_{i j t}$ & Time-variant & + \\
\hline Geographical Distance & $D I S_{i j t}$ & Time-invariant & - \\
\hline The Multilateral Resistance Term & $R E M_{j t}$ & Time-variant & + \\
\hline
\end{tabular}

(Note) The table expresses the expected signs of the variables in the gravity model

(Source) Authors' compilation; GDP = Gross Domestic Product; WTO = World Trade Organization

According to the estimated signs, listed in Table 2, we expect that GDP, representing economic size, positively impacts all disaggregated trade flows and accelerate manufactured-based trade and raw material-based trade growth between each BRICS member and a trading partner. The impact of the difference in income may be vague. $D Y P$ 's coefficient can have a positive sign if the $\mathrm{H}-\mathrm{O}$ bilateral trade pattern exists between countries (Baskaran et al. 2011); otherwise, this variable's negative sign can appear under the Linder hypothesis, which was proposed by Burenstam Linder in 1961. He pointed out that differences in preferences constitute a significant trade barrier between countries.

A positive relationship is expected between a bilateral exchange rate and trade flows. In other words, any increase in the real effective exchange rate for each BRICS member leads to an increase in trade flows. It is also expected that the coefficient of trade openness may be positive. A negative relationship is expected to exist between geographical distance and trade flows, whereas multilateral resistance term is widely believed to expand trade flows. 


\section{Empirical results}

\section{A. Preliminary tests}

According to Hsiao, Hashem Pesaran, and Rich (2011) and Xu, Cai, and Fang (2016), (2016), panel data sets are likely to exhibit substantial cross-sectional dependence. Hence, one of the most important preliminary tests for panel data is the cross-sectional dependence test, which is conducted through three different tests: Breusch-Pagan Lagrange Multiplier (LM), Pesaran Scaled LM, and Pesaran Cross-sectional Dependence (CD). These tests are defined as follows.

Breusch-Pagan Lagrange Multiplier (LM):

$$
\text { Breusch - Pagan } L M=\sum_{i=1}^{N-1} \sum_{j=i+1}^{N} T_{i j} \hat{\rho}_{i j}^{2} \rightarrow \chi^{2} \frac{N(N-1)}{2}
$$

where $\hat{\rho}_{i j}$ indicates the correlation coefficients from the residuals of the model. Pesaran Scaled LM:

$$
\text { Pesaran Scaled } L M=\sqrt{\frac{1}{N(N-1)}} \sum_{i=1}^{N-1} \sum_{j=i+1}^{N}\left(T_{i j} \hat{\rho}_{i j}^{2}-1\right) \rightarrow N(0,1)
$$

Pesaran CD:

$$
\text { Pesaran } C D=\sqrt{\frac{2}{N(N-1)}} \sum_{i=1}^{N-1} \sum_{j=i+1}^{N} T_{i j} \hat{\rho}_{i j}^{2} \rightarrow N(0,1)
$$

The results of these three tests, as shown in Appendix 1, indicate that the null hypothesis (no cross-section dependence on residuals) is strongly rejected at the $5 \%$ significance level, revealing that all of our series have cross-sectional dependence.

Prior to the application of the panel cointegration approach, we tested for the presence of stationarity among series. Due to various years have certain disturbances, series always tends to experience random drift. Accordingly, it is essential to implement unit root tests to determine whether or not the series are stationary from 2001 to 2015. We use two popular panel unit root tests: the Im, Pesaran, and Shin (IPS) and the ADF-Fisher Chi-square. These two panel unit root tests specify a separate ADF regression for each cross section (Al-mulali and Binti Che Sab 2012): 


$$
\Delta y_{i t}=\alpha y_{i t-1} \sum_{j=1}^{p_{i}} \beta_{i j} \Delta y_{i t-j}+X_{i t}^{\prime} \delta+\varepsilon_{i t}
$$

where the null hypothesis is $\mathrm{H}_{0}: \alpha=0$, for all $i$. The results of the unit root tests reveal that the series are not stationary at all levels, but are stationary at the first difference.

In the next step, we followed the panel cointegration test proposed by Pedroni $(1999,2004)$ and apply it in the case of our gravity models. The test contains two sets of $F$-statistics. The first set, based on the within dimension approach, includes panel $v$-statistic, $p$-statistic, panel $P P$-statistic, and panel $A D F$-statistic. These statistics pool the autoregressive coefficients across different BRICS members or the unit root tests on the estimated residuals considering time factors and heterogeneity across BRICS members. The second set is named the group mean panel cointegration statistics using the between dimension approach and comprises three statistics: group $p$-statistic, group $p p$-statistic, and group $A D F$-statistic. All seven statistics are distributed asymptotically as standard normal (Apergis and Payne 2009). According to the results, the null hypothesis of no cointegration is rejected at the $1 \%$ significance level.

\section{B. Gravity-trade model}

Similar to the extant literature on the gravity model, we employed a panel cointegration estimator called the Fully Modified Ordinary Least Squares (FMOLS) to examine the BRICS's bilateral trade patterns within the gravity-trade framework. With regard to the selection of the FMOLS, it should be noted that despite dissimilar views of the estimation of panel cointegration e.g., Pedroni (1996, 2001), who suggest using the FMOLS estimator; Fixed Effects by Cheng and Wall (2005) and Anderson and Wincoop (2003); and the Random Effects by Soren, Behnhard, and Glauben (2014), a number of studies such as those by Fidrmuc (2009), Rasoulinezhad and Kang (2016), Popova and Rasoulinezhad (2016), Nasre Esfahani and Rasoulinezhad (2017) and Rasoulinezhad (2017) proved the similarity of panel cointegration estimators' results.

The empirical results for the FMOLS gravity-trade estimations are as follows. 


\section{- Group I: The African group}

The African group, comprising 28\% of all UN members, is a large export market for BRICS. Table 3 lists the estimation results of the gravity trade models for bilateral integration trade between each BRICS member and the African group.

Whereas joint GDP has a significantly strong coefficient for BICS (Brazil, India, China, and South Africa)-African group trade flows in both models, it is only $0.44 \%$ for Russian manufactured trade (Model A) with the African group. This dissimilar pattern of Russia is due to its energy-based of trade structure. The sign of the coefficient for the difference in income reveals the existence of the Linder hypothesis between BICS and the African group, while it has negative sign in case of Russia-African group trade which proves the $\mathrm{H}-\mathrm{O}$ trade pattern. For trade openness, although the sign of this variable is positive for the trade of all BRICS members with the African group, it has the smallest magnitude in the case of China. Regarding the bilateral exchange rate, it is clear that China's national currency is the strongest national currency among other members' national currency. A 1\% depreciation in the Chinese Yuan increases the trade flow of this country with the African region by nearly $0.65 \%$ and $0.69 \%$ in manufactured goods trade and raw material trade, respectively, whereas a $1 \%$ depreciation in the Brazilian Real, Russian Ruble, Indian Rupee, and South African Rand increases their trade volume with the African group by approximately $0.08 \%, 0.23 \%, 0.22 \%$, and $0.01 \%$, respectively. In the case of geographical distance, it has negative sign for all BRICS members trade with the African countries. However, the magnitude of this variable for China is the smallest among other BRICS members. The multilateral resistance term, as expected, has a positive effect on BRICS-African group countries in both disaggregated trade, i.e., manufactured goods and raw material trade flows. 
Table 3. Gravity estimation: BRICS-African group trade

\begin{tabular}{|c|c|c|c|}
\hline Country & Variables & Model A & Model B \\
\hline \multirow{6}{*}{ Brazil } & Joint GDP & $0.90(0.00)$ & $0.71(0.00)$ \\
\hline & Difference in income & $0.66(0.00)$ & $0.70(0.01)$ \\
\hline & Trade Openness & $0.26(0.02)$ & $0.22(0.00)$ \\
\hline & Bilateral exchange rate & $0.06(0.04)$ & $0.10(0.00)$ \\
\hline & Geographical distance & $-0.11(0.00)$ & $-0.16(0.00)$ \\
\hline & The Multilateral Resistance Term & $0.09(0.00)$ & $0.09(0.00)$ \\
\hline \multirow{6}{*}{ Russia } & Joint GDP & $0.44(0.00)$ & $0.98(0.00)$ \\
\hline & Difference in income & $-0.54(0.00)$ & $-0.59(0.00)$ \\
\hline & Trade Openness & $0.31(0.00)$ & $0.19(0.01)$ \\
\hline & Bilateral exchange rate & $0.25(0.00)$ & $0.21(0.00)$ \\
\hline & Geographical distance & $-0.19(0.00)$ & $-0.17(0.00)$ \\
\hline & The Multilateral Resistance Term & $0.01(0.00)$ & $0.04(0.02)$ \\
\hline \multirow{6}{*}{ India } & Joint GDP & $0.93(0.01)$ & $0.89(0.00)$ \\
\hline & Difference in income & $0.49(0.00)$ & $0.41(0.00)$ \\
\hline & Trade Openness & $0.51(0.00)$ & $0.53(0.04)$ \\
\hline & Bilateral exchange rate & $0.21(0.00)$ & $0.22(0.00)$ \\
\hline & Geographical distance & $-0.09(0.01)$ & $-0.10(0.00)$ \\
\hline & The Multilateral Resistance Term & $0.18(0.00)$ & $0.21(0.00)$ \\
\hline \multirow{6}{*}{ China } & Joint GDP & $1.09(0.00)$ & $1.00(0.00)$ \\
\hline & Difference in income & $0.71(0.00)$ & $0.74(0.00)$ \\
\hline & Trade Openness & $0.19(0.00)$ & $0.16(0.00)$ \\
\hline & Bilateral exchange rate & $0.65(0.00)$ & $0.69(0.00)$ \\
\hline & Geographical distance & $-0.01(0.00)$ & $-0.03(0.00)$ \\
\hline & The Multilateral Resistance Term & $0.32(0.00)$ & $0.39(0.01)$ \\
\hline \multirow{6}{*}{ South Africa } & Joint GDP & $0.89(0.00)$ & $0.91(0.03)$ \\
\hline & Difference in income & $0.28(0.00)$ & $0.27(0.00)$ \\
\hline & Trade Openness & $0.44(0.01)$ & $0.48(0.02)$ \\
\hline & Bilateral exchange rate & $0.01(0.00)$ & $0.01(0.00)$ \\
\hline & Geographical distance & $-0.32(0.00)$ & $-0.39(0.00)$ \\
\hline & The Multilateral Resistance Term & $0.08(0.00)$ & $0.11(0.00)$ \\
\hline
\end{tabular}

(Note) Numbers in brakets show $p$-value, The table represents the estmation results of gravity trade model in the case of BRICS-African group.

(Source) Authors' compilation from Eviews 9.0. GDP = Gross Domestic Product 


\section{- Group II: Asia Pacific group}

Potential commodities trading efficiencies of the Asia Pacific nations in the last decades (Contessi 2016) pushed the BRICS members to draw their trade policies mainly to this region, especially with Japan, South Korea and Malaysia. The gravity trade estimations presented in Table 4 prove a strong influence of economic size in bilateral trade between BRICS and the Asia Pacific group. Only in the case of manufactured goods trade between Russia and the Asia Pacific group, this variable has the smallest magnitude which is mainly due to the trade structure of this country. The coefficient of the difference in income show evidence of trade dissimilarity among the BRICS members. The positive sign for BICS proves the Linder hypothesis, whereas the negative sign of this variable supports a $\mathrm{H}-\mathrm{O}$ trade pattern of Russia with the Asia Pacific group. The main reason is the static and undiversified trade pattern of Russia, which focused on non-renewable energy trade (Garanina 2009). Furthermore, the effect of trade openness is statistically significant and positive for the BRICS-Asia Pacific trade flow, whereas it has not a big impact on the China-Asia Pacific region trade. A 1\% increase in trade openness level accelerates the China-Asia Pacific region trade by nearly $13 \%$ (average of $0.11 \%$ and $0.14 \%$ ), while it increases the trade of Brazil, Russia, India and South Africa with the Asia Pacific nations by approximately $0.41 \%, 0.16 \%, 0.22 \%$ and $0.46 \%$, respectively. The market penetration strategy of China which is adoptable to various trade barriers of countries leads to less impact of trade openness level on Chinese trade framework. Moreover, geographical distance and the multilateral resistance term have expected signs. It should be noted that the magnitude of geographical distance's coefficient in the case of China is the smallest one among other BRICS economies (Table 4). 
Table 4. Gravity estimation: BRICS-Asia Pacific group trade

\begin{tabular}{|c|c|c|c|}
\hline Country & Variables & Model A & Model B \\
\hline \multirow{6}{*}{ Brazil } & Joint GDP & $1.02(0.00)$ & $1.04(0.00)$ \\
\hline & Difference in income & $0.34(0.00)$ & $0.38(0.03)$ \\
\hline & Trade Openness & $0.42(0.03)$ & $0.40(0.01)$ \\
\hline & Bilateral exchange rate & $0.10(0.00)$ & $0.13(0.00)$ \\
\hline & Geographical distance & $-0.38(0.01)$ & $-0.35(0.00)$ \\
\hline & The Multilateral Resistance Term & $0.14(0.00)$ & $0.16(0.00)$ \\
\hline \multirow{6}{*}{ Russia } & Joint GDP & $0.51(0.00)$ & $1.12(0.00)$ \\
\hline & Difference in income & $-0.21(0.00)$ & $-0.27(0.00)$ \\
\hline & Trade Openness & $0.14(0.00)$ & $0.17(0.01)$ \\
\hline & Bilateral exchange rate & $0.35(0.00)$ & $0.39(0.00)$ \\
\hline & Geographical distance & $-0.21(0.04)$ & $-0.25(0.00)$ \\
\hline & The Multilateral Resistance Term & $0.29(0.01)$ & $0.30(0.00)$ \\
\hline \multirow{6}{*}{ India } & Joint GDP & $1.25(0.00)$ & $1.19(0.03)$ \\
\hline & Difference in income & $0.47(0.00)$ & $0.51(0.00)$ \\
\hline & Trade Openness & $0.21(0.02)$ & $0.22(0.01)$ \\
\hline & Bilateral exchange rate & $0.14(0.00)$ & $0.12(0.00)$ \\
\hline & Geographical distance & $-0.46(0.00)$ & $-0.44(0.00)$ \\
\hline & The Multilateral Resistance Term & $0.07(0.00)$ & $0.09(0.00)$ \\
\hline \multirow{6}{*}{ China } & Joint GDP & $1.03(0.00)$ & $1.04(0.00)$ \\
\hline & Difference in income & $0.88(0.01)$ & $0.85(0.01)$ \\
\hline & Trade Openness & $0.11(0.00)$ & $0.14(0.00)$ \\
\hline & Bilateral exchange rate & $0.81(0.03)$ & $0.76(0.00)$ \\
\hline & Geographical distance & $-0.03(0.00)$ & $-0.00(0.00)$ \\
\hline & The Multilateral Resistance Term & $0.21(0.00)$ & $0.24(0.00)$ \\
\hline \multirow{6}{*}{ South Africa } & Joint GDP & $0.97(0.00)$ & $1.00(0.00)$ \\
\hline & Difference in income & $0.33(0.00)$ & $0.35(0.00)$ \\
\hline & Trade Openness & $0.45(0.04)$ & $0.47(0.01)$ \\
\hline & Bilateral exchange rate & $0.09(0.00)$ & $0.08(0.01)$ \\
\hline & Geographical distance & $-0.51(0.00)$ & $-0.56(0.00)$ \\
\hline & The Multilateral Resistance Term & $0.21(0.00)$ & $0.19(0.04)$ \\
\hline
\end{tabular}

(Note) Numbers in brakets show $p$-value, The table represents the estmation results of gravity trade model in the case of BRICS-Asia Pacific group.

(Source) Authors' compilation from Eviews 9.0. GDP = Gross Domestic Product 


\section{- Group III: Eastern European group}

The Eastern European economies, currently having small and under developed internal markets (Martinez-Zarzoso and Johannsen 2017), are potential markets for the BRICS's commodities. Economic size has a positive impact on each member of BRICS's trade with the Eastern European group. It has the largest magnitude of trade between Russia and this region. The main reason is the historical economic ties between these countries as the Soviet Union. The Eastern European region highly depends on trade relations with Russia (Malle 2017). A review of the coefficient sign of the difference in income shows that all BICS (Brazil, India, China, and South Africa) economies follow the Linder hypothesis, whereas Russia-Eastern European nations' trade is in line with the $\mathrm{H}-\mathrm{O}$ pattern. In addition, the signs of the bilateral exchange rate coefficients are similar for the BRICS economies, which reveal that a $1 \%$ depreciation of the BRICS' national currencies against the Eastern European nations' currencies increases the bilateral trade volume. Geographical distance has a negative impact on BRICS-Eastern Euripean region's trade flows. However, the magnitude of this impact is quite small in cases of Russia and China. The main reason is that Russian economy ties chiefly with the economy of the Eastern European nations, therefore transportation cost is not so important in trade flows between Russia and this region. For China, transportation cost is not a challenge to deal in trade with this region. Because this region is a potential market for Chinese traders which pushes and motivates China to improve its penetration in the region's market without serious attention to the transprtation cost. Furthermore, the MRT shows a positive impact on each member of BRICS's trade with this region. 
Table 5. Gravity estimation: BRICS-Eastern European trade

\begin{tabular}{|c|c|c|c|}
\hline Country & Variables & Model A & Model B \\
\hline \multirow{6}{*}{ Brazil } & Joint GDP & $0.87(0.01)$ & $0.85(0.00)$ \\
\hline & Difference in income & $0.29(0.01)$ & $0.31(0.00)$ \\
\hline & Trade Openness & $0.35(0.01)$ & $0.35(0.04)$ \\
\hline & Bilateral exchange rate & $0.09(0.00)$ & $0.02(0.00)$ \\
\hline & Geographical distance & $-0.52(0.00)$ & $-0.58(0.00)$ \\
\hline & The Multilateral Resistance Term & $0.18(0.00)$ & $0.14(0.00)$ \\
\hline \multirow{6}{*}{ Russia } & Joint GDP & $1.07(0.00)$ & $1.05(0.00)$ \\
\hline & Difference in income & $-0.42(0.00)$ & $-0.49(0.00)$ \\
\hline & Trade Openness & $0.01(0.00)$ & $0.00(0.00)$ \\
\hline & Bilateral exchange rate & $0.79(0.00)$ & $0.66(0.00)$ \\
\hline & Geographical distance & $-0.11(0.01)$ & $-0.16(0.03)$ \\
\hline & The Multilateral Resistance Term & $0.05(0.00)$ & $0.08(0.00)$ \\
\hline \multirow{6}{*}{ India } & Joint GDP & $0.96(0.00)$ & $0.92(0.00)$ \\
\hline & Difference in income & $0.21(0.02)$ & $0.21(0.00)$ \\
\hline & Trade Openness & $0.38(0.00)$ & $0.35(0.00)$ \\
\hline & Bilateral exchange rate & $0.09(0.00)$ & $0.11(0.00)$ \\
\hline & Geographical distance & $-0.36(0.03)$ & $-0.36(0.00)$ \\
\hline & The Multilateral Resistance Term & $0.15(0.00)$ & $0.19(0.00)$ \\
\hline \multirow{6}{*}{ China } & Joint GDP & $1.12(0.00)$ & $0.98(0.00)$ \\
\hline & Difference in income & $0.79(0.02)$ & $0.81(0.00)$ \\
\hline & Trade Openness & $0.05(0.00)$ & $0.07(0.00)$ \\
\hline & Bilateral exchange rate & $0.78(0.00)$ & $0.76(0.00)$ \\
\hline & Geographical distance & $-0.04(0.02)$ & $-0.05(0.03)$ \\
\hline & The Multilateral Resistance Term & $0.11(0.00)$ & $0.16(0.00)$ \\
\hline \multirow{6}{*}{ South Africa } & Joint GDP & $0.85(0.00)$ & $0.85(0.00)$ \\
\hline & Difference in income & $0.26(0.03)$ & $0.29(0.00)$ \\
\hline & Trade Openness & $0.61(0.00)$ & $0.55(0.04)$ \\
\hline & Bilateral exchange rate & $0.10(0.00)$ & $0.05(0.00)$ \\
\hline & Geographical distance & $-0.59(0.00)$ & $-0.57(0.00)$ \\
\hline & The Multilateral Resistance Term & $0.19(0.00)$ & $0.27(0.00)$ \\
\hline
\end{tabular}

(Note) Numbers in brakets show $p$-value, The table represents the estmation results of gravity trade model in the case of BRICS-Eastern European group.

(Source) Authors' compilation from Eviews 9.0. GDP = Gross Domestic Product 


\section{- Group IV: Latin American and Caribbean group}

The main goal of group IV is also to increase the degree of economic integration with the world (Thoumi 1989) which motivates doing trade with emerging economies. Because Brazil (Table 6), is considered part of Latin America, has a stronger effect on its bilateral trade with other Latin American and Caribbean nations (LAC), whereas the coefficients of this variable is the lowest in the case of Russia. Similar to the previous estimations, the negative sign of the difference in income for Russia supports the $\mathrm{H}-\mathrm{O}$ hypothesis, whereas for other members (BICS), the Linder hypothesis is supported by the positive sign of the coefficient. Moreover, trade openness has a statistically significant on the BRICS-LAC's trade flows. Regarding the bilateral exchange rate variable, it has the largest impact in the case of China-LAC's trade flows which proves the power of China's national currency than other BRICS members's. While geographical distance as the proxy of transportation cost has a negative effect on BRICS and LAC's trade flows, the MRT has positive sign which accelerates the BRICS-LAC's trade flows. 
Table 6. Gravity estimation: BRICS-Latin American and Caribbean trade

\begin{tabular}{|c|c|c|c|}
\hline Country & Variables & Model A & Model B \\
\hline \multirow{6}{*}{ Brazil } & Joint GDP & $0.94(0.03)$ & $0.98(0.02)$ \\
\hline & Difference in income & $0.41(0.00)$ & $0.43(0.00)$ \\
\hline & Trade Openness & $0.27(0.00)$ & $0.31(0.01)$ \\
\hline & Bilateral exchange rate & $0.12(0.00)$ & $0.11(0.00)$ \\
\hline & Geographical distance & $-0.42(0.00)$ & $-0.39(0.00)$ \\
\hline & The Multilateral Resistance Term & $0.30(0.00)$ & $0.28(0.03)$ \\
\hline \multirow{6}{*}{ Russia } & Joint GDP & $0.82(0.03)$ & $0.86(0.02)$ \\
\hline & Difference in income & $-0.19(0.00)$ & $-0.15(0.00)$ \\
\hline & Trade Openness & $0.34(0.00)$ & $0.28(0.00)$ \\
\hline & Bilateral exchange rate & $0.68(0.00)$ & $0.71(0.00)$ \\
\hline & Geographical distance & $-0.33(0.03)$ & $-0.35(0.00)$ \\
\hline & The Multilateral Resistance Term & $0.11(0.00)$ & $0.18(0.00)$ \\
\hline \multirow{6}{*}{ India } & Joint GDP & $1.00(0.00)$ & $0.99(0.00)$ \\
\hline & Difference in income & $0.52(0.01)$ & $0.57(0.00)$ \\
\hline & Trade Openness & $0.41(0.00)$ & $0.49(0.00)$ \\
\hline & Bilateral exchange rate & $0.18(0.00)$ & $0.23(0.03)$ \\
\hline & Geographical distance & $-0.19(0.03)$ & $-0.21(0.00)$ \\
\hline & The Multilateral Resistance Term & $0.28(0.00)$ & $0.26(0.00)$ \\
\hline \multirow{6}{*}{ China } & Joint GDP & $1.04(0.00)$ & $1.05(0.00)$ \\
\hline & Difference in income & $0.88(0.02)$ & $0.87(0.00)$ \\
\hline & Trade Openness & $0.08(0.00)$ & $0.09(0.00)$ \\
\hline & Bilateral exchange rate & $0.81(0.00)$ & $0.77(0.00)$ \\
\hline & Geographical distance & $-0.03(0.00)$ & $-0.02(0.01)$ \\
\hline & The Multilateral Resistance Term & $0.27(0.00)$ & $0.24(0.00)$ \\
\hline \multirow{6}{*}{ South Africa } & Joint GDP & $0.91(0.03)$ & $0.92(0.01)$ \\
\hline & Difference in income & $0.16(0.00)$ & $0.17(0.00)$ \\
\hline & Trade Openness & $0.56(0.00)$ & $0.52(0.00)$ \\
\hline & Bilateral exchange rate & $0.13(0.00)$ & $0.18(0.00)$ \\
\hline & Geographical distance & $-0.67(0.02)$ & $-0.72(0.04)$ \\
\hline & The Multilateral Resistance Term & $0.31(0.00)$ & $0.37(0.00)$ \\
\hline
\end{tabular}

(Note) Numbers in brakets show $p$-value, The table represents the estmation results of gravity trade model in the case of BRICS-Latin America and Caribbean group.

(Source) Authors' compilation from Eviews 9.0. GDP = Gross Domestic Product 


\section{- Group V: Western European and others group}

The Western European and Other group, featured by advanced economic system and technology-based export pattern, always receives attention from the BRICS. The estimation findings in Table 7 show the strongest effect of economic size for all BRICS members among the UN-classified group V. Based on the existence of the energy-trade pattern between group $\mathrm{V}$ and Russia, the negative sign of coefficient of difference in income proves the $\mathrm{H}-\mathrm{O}$ hypothesis, whereas this variable has a positive sign for the rest of the BRICS members, supporting the Linder hypothesis. The coefficients of the bilateral exchange rate among BRICS economies show that any depreciation of the BRICS currencies increases the trade flow between the countries of BRICS and Western European and Other group. Furthermore, trade openness and the MRT have a positive impact on the BRICS-Western European region, while geographical distance negatively affects trade flows of BRICS with the Western European and others group. It should be noted that bilateral exchange rate and geographical distance have the smallest effects on China-Western European region which reveal the power of Chinese Yuan and less importance of transportation cost. 
Table 7. Gravity estimation: BRICS-Western European and others group trade

\begin{tabular}{|c|c|c|c|}
\hline Country & Variables & Model A & Model B \\
\hline \multirow{6}{*}{ Brazil } & Joint GDP & $1.13(0.00)$ & $1.17(0.02)$ \\
\hline & Difference in income & $0.22(0.00)$ & $0.18(0.00)$ \\
\hline & Trade Openness & $0.31(0.03)$ & $0.30(0.03)$ \\
\hline & Bilateral exchange rate & $0.03(0.00)$ & $0.04(0.00)$ \\
\hline & Geographical distance & $-0.21(0.00)$ & $-0.14(0.00)$ \\
\hline & The Multilateral Resistance Term & $0.19(0.01)$ & $0.18(0.01)$ \\
\hline \multirow{6}{*}{ Russia } & Joint GDP & $1.10(0.00)$ & $1.09(0.03)$ \\
\hline & Difference in income & $-0.10(0.00)$ & $-0.09(0.00)$ \\
\hline & Trade Openness & $0.19(0.00)$ & $0.24(0.00)$ \\
\hline & Bilateral exchange rate & $0.29(0.00)$ & $0.30(0.00)$ \\
\hline & Geographical distance & $-0.10(0.00)$ & $-0.11(0.00)$ \\
\hline & The Multilateral Resistance Term & $0.29(0.00)$ & $0.29(0.00)$ \\
\hline \multirow{6}{*}{ India } & Joint GDP & $1.13(0.00)$ & $1.07(0.00)$ \\
\hline & Difference in income & $0.14(0.00)$ & $0.19(0.00)$ \\
\hline & Trade Openness & $0.38(0.00)$ & $0.35(0.00)$ \\
\hline & Bilateral exchange rate & $0.12(0.04)$ & $0.09(0.01)$ \\
\hline & Geographical distance & $-0.27(0.00)$ & $-0.31(0.00)$ \\
\hline & The Multilateral Resistance Term & $0.09(0.00)$ & $0.04(0.00)$ \\
\hline \multirow{6}{*}{ China } & Joint GDP & $1.20(0.00)$ & $1.16(0.00)$ \\
\hline & Difference in income & $0.74(0.00)$ & $0.78(0.00)$ \\
\hline & Trade Openness & $0.18(0.00)$ & $0.23(0.00)$ \\
\hline & Bilateral exchange rate & $0.79(0.00)$ & $0.84(0.00)$ \\
\hline & Geographical distance & $-0.00(0.00)$ & $-0.01(0.00)$ \\
\hline & The Multilateral Resistance Term & $0.36(0.00)$ & $0.27(0.00)$ \\
\hline \multirow{6}{*}{ South Africa } & Joint GDP & $0.98(0.00)$ & $1.05(0.02)$ \\
\hline & Difference in income & $0.24(0.00)$ & $0.21(0.00)$ \\
\hline & Trade Openness & $0.49(0.00)$ & $0.50(0.00)$ \\
\hline & Bilateral exchange rate & $0.05(0.00)$ & $0.07(0.00)$ \\
\hline & Geographical distance & $-0.71(0.00)$ & $-0.65(0.01)$ \\
\hline & The Multilateral Resistance Term & $0.15(0.00)$ & $0.21(0.00)$ \\
\hline
\end{tabular}

(Note) Numbers in brakets show $p$-value, The table represents the estmation results of gravity trade model in the case of BRICS-Western European and others group.

(Source) Authors' compilation from Eviews 9.0. GDP = Gross Domestic Product 


\section{Conclusion}

This study investigates the trade integration patterns for BRICS members using the 2014-UN Regional Groups and the gravity-panel data over the period of 2001 2015. The data include GDP, difference in income, trade openness, bilateral exchange rate, geographical distance, and the Multilateral Resistance Term (MRT). The results find a dissimilar integration trade patterns in manufactured products and raw materials, among the BRICS members, particularly Russia. This finding is in line with Medvedev (2015) and Makhmudova and Koreleva (2016), who claim that, Russia has faced geopolitical tensions in the recent decade that destabilized its economy and has a particular trade patterns. The rest of our findings are summarized as follows.

From the coefficients of the bilateral exchange rate for BRICS member states in trading with UN member states, the Chinese currency, Yuan, shows stronger impacts on trade among the currencies of BRICS countries. It is consistent with the results of Orastean (2013)'s study. The main reason for the higher power of Chinese Yuan would be the dominance of this country in the BRICS's total trade flows. According to the Trade Map database, China contributes $67.8 \%$ to the total BRICS's imports and $72.2 \%$ to the total BRICS's exports in 2016.

The coefficient of different in incomes reveal that the Russian trade model is based on the $\mathrm{H}-\mathrm{O}$ pattern in both manufactured products trade and raw material trade, whereas four other countries follow the Linder hypothesis in both products trade. The result is attributable to the excessive dependence of Russian trade on natural resources, such as oil and gas, and its tendency to deal trade with trade partners who have not similar income level with Russian Federation.

The size of the economy are significant for variables particularly two groups of Western European and Asia Pacific countries in both manufactured goods and raw material trade patterns. The existence of the countries, such as South Korea, Japan, China, India, Qatar, Singapore, and the UAE, in the group of Asia Pacific countries, as well as the presence of advanced economies such as Germany, England, the United States, France, Switzerland, the Netherlands, and Canada in the Western European Countries and Others group, appear to attract BRICS member states. In contrast, the attraction toward Latin America, Eastern Europe, and Africa is more pronounced for China. 
Regarding the effect of geographical distance as a proxy for transportation cost, China and India appear to have better transport infrastructures than the other three BRICS member states. It is consistent with the findings of studies by Pradhan and Bagchi (2013), Maparu and Mazumder (2017), Zhang (2008), Li, Wen, and Jiang (2017) on the development of transport infrastructures in India. The project of One Belt, One Road of China would be a policy which lowers more the transportation cost of China and India as well, fostering their role in BRICS and global trade flows. Overall, the results show the higher level of trade integration of China and India with different regions. Further research should try to model integration patterns, for exports and imports of BRICS economies, seperately. It helps policy makers to find out more details about trade integration patterns of BRICS with different regions.

Received 7 November 2017, Revised 30 January 2018, Accepted 12 February 2018 


\section{References}

Alessandria, G., H. Choi, and D. Lu. "Trade Integration and the Trade Balance in China." IMF Economic Review 65 (3) (2017): 633-674.

Al-mulali, Usama, and Che Normee Binti Che Sab. "The Impact of Energy Consumption and CO2 Emission on the Economic Growth and Financial Development in the Sub Saharan African Countries.” Energy 39 (1). Elsevier Ltd. (2012): 180-186. doi:10.1016/j.energy.2012.01.032.

Anderson, J.E., and E.V. Wincoop. "Gravity with Gravitas: A Solution to the Border Puzzle." The American Economic Review 93 (1) (2003): 170-192.

Apergis, Nicholas, and James E. Payne. "CO2 Emissions, Energy Usage, and Output in Central America.” Energy Policy 37 (8). Elsevier. (2009): 3282-3286. doi:10.1016/ j.enpol.2009.03.048.

Ayhan Kose, M., and E.O. Ozturk. "A World of Change." Finance and Development 51 (3) (2014): 6-11.

Baier, Scott L., and Jeffrey H. Bergstrand. "Do Free Trade Agreements Actually Increase Members' International Trade?” Journal of International Economics 71 (1) (2007): 72-95. doi:10.1016/j.jinteco.2006.02.005.

Baskaran, T., F. Blochl, T. Brick, and F.J. Theis. "The Heckscher-Ohlin Model and the Network Structure of International Trade." International Review of Economics and Finance 30 (5) (2011): 764-782.

Behrens, K., C. Gaigne, G. Ottaviano, and J. Thisse. "Countries, Regions and Trade: On the Welfare Impacts of Economic Integration." European Economic Review 51 (5) (2007): 1277-1301. 
Bezuidenhout, H., and C. Claassen. "South African Trade Hegemony: Is the South Africa-EU Trade, Development and Cooperation Agreement Heading for a BRICS Wall?" South African Journal of International Affairs 20 (2) (2013): 227-246.

Caporale, Guglielmo Maria, Anamaria Sova, and Robert Sova. "Trade Flows and Trade Specialisation: The Case of China." China Economic Review 34. Elsevier B.V. (2015): 261-273. doi:10.1016/j.chieco.2015.03.010.

Carrilo-Tudela, C., and C.A. Li. "Trade Blocks and the Gravity Model: Evidence from Latin American Countries." Journal of Economic Integration 19 (4) (2004): 667-689.

Chen, N., and D. Novy. "Gravity, Trade Integration, and Heterogeneity across Industries.” Journal of International Economics 85 (2) (2011): 206-211.

Cheng, I-Hui, and H.J. Wall. 2005. "Controlling for Heterogeneity in Gravity Models of Trade and Integration."

Clus-Rossouw, D., W. Viviers, and E. Loots. "Is There a Link between BRIC Foreign Direct Investment and SADC Export Performance?" Development Southern Africa 32 (6) (2015): 658-674.

Contessi, N.P. "Central Asia in Asia: Charting Growing Trans-Regional Linkages." Journal of Eurasian Studies 7 (1) (2016): 3-13.

De Mello-Sampayo, F. “Testing Competing Destinations Gravity Models-Evidence from BRIC International." The Journal of International Trade \& Economic Development 26 (3) (2017): 277-294.

Ekanayake, E.M., A. Mukherjee, and B. Veeramacheneni. "Trade Blocks and the Gravity Model: A Study of Economic Integration among Asian Developing Countries.” Journal of Economic Integration 25 (4) (2010): 627-643. 
Fadaee, M., A. Abolhasani, and B. Shaygani. "Survey of the Linder Theory in BRICS Countries Applying Different Exchange Rate Arrangements (GMM System)." Quarterly Journal of Quantitative Economics 1 (36) (2013): 131-166.

Fidrmuc, J. “Gravity Models in Integrated Panels.” Empirical Economics 37 (2009): $435-446$.

Fung, K.C., H. Hwang, F. Ng, and J. Seade. "Production Networks and International Trade: China, Brazil and Mexico.” World Development The North (34) (2015): 421429.

Garanina, O. "What Beyond Oil and Gas? Russian Trade Specialization in Manufactures.” Post-Communist Economies 21 (1) (2009): 1-29.

Gust, Ch., S. Leduc, and R. Vigfusson. "Trade Integration, Competition, and the Decline in Exchange Rate Pass through." Journal of Monetary Economics 57 (3) (2010): 309-324.

Hallett, A.H., and L. Pisciatelli. "Does Trade Integration Cause Convergence?" Economics Letters 75 (2) (2002): 165-170.

Hanson, G.H. "Economic Integration, Intraindustry Trade, and Frontier Regions." European Economic Review 40 (3-5) (1996): 941-949.

Hsiao, Ch., M. Hashem Pesaran, and A. Rich. "Diagnostic Tests of Cross-Section Independence for Limited Dependent Variable Panel Data Models." Oxford Bulletin of Economics and Statistics 74 (2) (2011): 253-277.

Izotov, D.A. "Liberalization of Russia's Trade with the European Union, BRICS, and Trans-Pacific Partnership Countries." Studies on Russian Economic Development 28 (3) (2007): 338-345. 
Jakab, Z.M., M.A. Kovacs, and A. Oszlay. "How Far Has Trade Integration Advanced?: An Analysis of the Actual and Potential Trade of Three Central and Eastern European Countries.” Journal of Comparative Economics 29 (2) (2001): 276292.

Kamal Naser, A.H. "Trade and Regional Integration: Analysis of the Effectiveness in the GCC." International Journal of Islamic and Middle Eastern Finance and Management 1 (2) (2008): 95-112.

Kraay, A., and J. Ventura. "Trade Integration and Risk Sharing." European Economic Review 46 (6) (2002): 1023-1048.

Kumar Mishra, A., J.N. Gadhia, N. Kubendran, and M. Sahoo.. "Trade Flows between India and Other BRICS Countries: An Empirical Analysis Using Gravity Model.” Global Business Review 16 (1) (2015): 107-122.

Kundu, N. "Bilateral Trade Balance of Bangladesh with BRICS Countries: A Static Panel Data Approach.” Journal of Economics and Development 17 (2) (2015): 53-68.

Li, J., J. Wen, and B. Jiang. "Spatial Spillover Effects of Transport Infrastructure in Chinese New Silk Road Economic Belt." International Journal of E-Navigation and Maritime Economy 6 (2017): 1-8.

Makhmudova, M.M., and A.M. Koreleva. "Foreign Trade Activity of the Russian Federation in the Current Context." International Journal of Economics and Financial Issues 6 (S2) (2016): 241-245.

Malle, S. "Russia and China in the 21st Century. Moving towards Cooperative Behavior.” Journal of Eurasian Studies 8 (2) (2017): 136-150.

Maparu, T.S, and T.N. Mazumder. "Transport Infrastructure, Economic Development and Urbanization in India (1990-2011): Is There Any Causal Relationship?" Transportation Research Part A: Policy and Practice 100 (2017): 319-336. 
Martinez-Zarzoso, I., and F. Johannsen. "Monetary Uncertainty and Trade in Eastern Europe and Central Asia: A Firm-Level Analysis.” Internatioanl Business Review 26 (3) (2017): 476-490.

Medvedev, D. "A New Reality: Russia and Global Challenges." Russian Journal of Economics 1 (2) (2015): 109-129.

Nasre Esfahani, M., and E. Rasoulinezhad. "Iran's Trade Policy of Asianization and de-Europeanization under Sanctions." Journal of Economic Studies 44 (4) (2017): $552-567$.

Nayyar Rahman, M. "Role of WTO in Promoting Merchandise Trade of BRICS." Transnational Corporations Review 8 (2) (2016): 138-150.

Olaru, S. "The Strategy and the Reasons of the Republic of Moldova's Association with European Union.” Procedia Economics and Finance 16 (2014): 381-390.

Orastean, R. "Chinese Currency Internationalization- Present and Expectations." Procedia Economics and Finance 6 (2013): 683-687.

Palmer, R.W., and D.R. Elliott. "Economic Integration of Poor Countries: Obstacles and Prospects." International Journal of Development Issues 2 (2) (2003): 59-75.

Pedroni, P. 1996. "Fully Modified OLS for Heterogenous Cointegrated Panels and the Case of Purchasing Power Parity.” 020.

—. "Critical Values for Cointegration Tests in Heterogeneous Panels with Multiple Regressors.” Oxford Bulletin of Economics and Statistics 61 (1999): 653-670.

—_ "Purchasing Power Parity Tests in Cointegrated Panels." Review Economics Statistics 83 (2001): 727-731. 
"Panel Cointegration; Asymptotic and Finite Sample Properties of Pooled Time Series Tests, With an Application to the PPP Hypothesis." Econometric Theory 20 (2004): 597-625.

Popova, L., and E. Rasoulinezhad. "Have Sanctions Modified Iran's Trade Policy? An Evidence of Asianization and De-Europeanization through the Gravity Model." Economies 4 (4) (2016): 1-15. doi:10.3390/economies4040024.

Portugal-Perez, A. “Assessing the Political Economy Factors on Trade Integration: Rules of Origin under NAFTA.” Journal of Economic Integration 26 (2) (2011): 276305.

Poyhonen, P. "ATentative Model for theVolume of Trade Between Countries." Weltwirtschaftliches Archiv 90 (1963): 93-99.

Pradhan, R.P., and T.P. Bagchi. "Effect of Transportation Infrastructure on Economic Growth in India: The VECM Approach." Research in Transportation Economics 38 (1) (2013): 139-148.

Rasoulinezhad, E. "Investigation of Sanctions and Oil Price Effects on the Iran-Russia Trade by Using the Gravity Model." Vestnik of St Petersburg University, Series 5 (Economics) 2 (2016): 68-84.

_ . "China's Foreign Trade Policy with OPEC Member Countries." Journal of Chinese Economic and Foreign Trade Policy 10 (1) (2017): 61-81.

Rasoulinezhad, E., and G.S. Kang. “A Panel Data Analysis of South Korea's Trade with OPEC Member Countries: The Gravity Model Approach.” Iranian Economic Review 20 (2) (2016): 203-224.

Rasoulinezhad, E. “China's Trade with OPEC Member Countries: A Panel-Gravity Model Approach.” The Chinese Economy 50 (5) (2017): 339-355. 
Shah Zainal Abidin, I., M. Haseeb, L. Wen Chiat, and M. Rabiul Islam. "Determinants of Malaysia-BRICS Trade Linkages: Gravity Model Approach." Investment Management and Financial Innovations 13 (2-2) (2016): 389-398.

Shaygani, B., F. Abolhasani Hastiani, A. Ghaffari, M. Sadeghi Shahdani, and M. Fadaee. "Effects of Exchange Rate Arrangements on Trade Cooperation in BRICS Countries." Asian Economic and Financial Review 5 (3) (2015): 563-578.

Sohn, B.H. 2010. "Regionalization of Trade and Investment in East Asia and Prospects for Further Regional Integration.” Journal of the Asia Pacific Economy 7 (2): 160181.

Soren, P., B. Behnhard, and T. Glauben. 2014. "Gravity Model Estimation: Fixed Effects vs. Random Intercept Poisson Pseudo Maximum Likelihood.” 148.

Surugiu, M., and C. Surugiu. "Interdependence between European Countries: Implications for Businesses and Marketing Framework." Procedia Economics and Finance 32 (2015): 131-138.

Taguchi, H. "Trade Integration of Thailand with Mekong Region: An Assessment Using Gravity Trade Model.” International Journal of Development Issues 12 (2) (2003): 175-187.

Thoumi, F.E. "Bilateral Trade Flows and Economic Integration in Latin America and the Caribbean.” World Development 17 (3) (1989): 421-429.

Tinbergen, T. 1962. Shaping the World Economy: Suggestions for an International Economic Policy. New York: The Twentieth Century Fund.

Weerakoon, D. "The Political Economy of Trade Integration in South Asia: The Role of India." The World Economy 33 (7) (2010): 916-927. 
$\mathrm{Xu}$, Q-H., Z-W Cai, and Y. Fang. "Panel Data Models with Cross-Sectional Dependence Selective Review." Applied Mathematics-A Journal of Chinese Universities 31 (2) (2016): 127-147.

Yavuz Cakir, M., and A. Kabundi. "Trade Shocks from BRIC to South Africa: A Global VAR Analysis.” Economic Modelling 32 (2013): 190-202.

Yin, W. "Agricultural Trading among BRICS Countries." Fudan Journal of the Humanities and Social Sciences 7 (3) (2014): 421-431.

Zhang, X. "Transport Infrastructure, Spatial Pillover and Economic Growth: Evidence from China." Frontiers of Economics in China 3 (2008): 585-597.

Zharikov, E.P., A.A. Kravchenko, O.O. Sergeeva, and V.V. Stetsyuk. "Econometric Estimation of Bilateral Transboundary Trade between Russia and China." International Journal of Economics and Financial Issues 6 (3) (2016): 1068-1671. 


\section{Appendices}

\section{Appendix 1: Residual cross-section dependence test}

\begin{tabular}{|c|c|c|c|c|}
\hline \multicolumn{2}{|c|}{ TMAN-Gravity model } & $\begin{array}{c}\text { Breusch- } \\
\text { Pagan LM }\end{array}$ & $\begin{array}{c}\text { Pesaran } \\
\text { Scaled LM }\end{array}$ & Pesaran CD \\
\hline \multirow{15}{*}{$\begin{array}{l}\text { The African } \\
\text { group }\end{array}$} & Brazil $_{\text {Model I }}$ & $1079.9(0.00)$ & $6.58(0.00)$ & $5.60(0.00)$ \\
\hline & Brazil $_{\text {Model II }}$ & $1092.4(0.00)$ & $6.89(0.00)$ & $3.30(0.00)$ \\
\hline & Brazil $_{\text {Model III }}$ & $1450.72(0.00)$ & $15.96(0.00)$ & $14.31(0.00)$ \\
\hline & Russia $_{\text {Model I }}$ & $1323.15(0.00)$ & $12.73(0.00)$ & $16.73(0.00)$ \\
\hline & Russia $_{\text {Model II }}$ & $1433.09(0.00)$ & $15.52(0.00)$ & $5.06(0.00)$ \\
\hline & Russia $_{\text {Model III }}$ & $1304.46(0.00)$ & $12.26(0.00)$ & $12.56(0.00)$ \\
\hline & India $_{\text {Model I }}$ & $1277.04(0.00)$ & $11.67(0.00)$ & $10.34(0.00)$ \\
\hline & India $_{\text {Model II }}$ & $1095.68(0.00)$ & $7.14(0.00)$ & $3.32(0.00)$ \\
\hline & India $_{\text {Model III }}$ & $1550.67(0.00)$ & $13.71(0.00)$ & $12.89(0.00)$ \\
\hline & China $_{\text {Model I }}$ & $1489.15(0.00)$ & $14.23(0.00)$ & $12.63(0.00)$ \\
\hline & China $_{\text {Model II }}$ & $1265.70(0.00)$ & $16.52(0.00)$ & $14.93(0.00)$ \\
\hline & China $_{\text {Model III }}$ & $1335.03(0.00)$ & $6.38(0.00)$ & $4.60(0.00)$ \\
\hline & South Africa ${ }_{\text {Model I }}$ & $1046.12(0.00)$ & $5.72(0.00)$ & $4.84(0.00)$ \\
\hline & South Africa Model II $_{\text {II }}$ & $1172.81(0.00)$ & $8.93(0.00)$ & $7.15(0.00)$ \\
\hline & South Africa ${ }_{\text {Model III }}$ & $1207.08(0.00)$ & $9.80(0.00)$ & $8.17(0.00)$ \\
\hline \multirow{15}{*}{$\begin{array}{c}\text { The Asia } \\
\text { Pacific group }\end{array}$} & Brazil $_{\text {Model I }}$ & $1404.96(0.00)$ & $15.36(0.00)$ & $14.92(0.00)$ \\
\hline & Brazil $_{\text {Model II }}$ & $1284.04(0.00)$ & $16.74(0.00)$ & $13.11(0.00)$ \\
\hline & Brazil $_{\text {Model III }}$ & $1566.52(0.00)$ & $9.63(0.00)$ & $7.13(0.00)$ \\
\hline & Russia $_{\text {Model I }}$ & $1512.10(0.00)$ & $14.37(0.00)$ & $13.39(0.00)$ \\
\hline & Russia $_{\text {Model II }}$ & $1205.66(0.00)$ & $14.88(0.00)$ & $12.08(0.00)$ \\
\hline & Russia $_{\text {Model III }}$ & $1472.69(0.00)$ & $13.31(0.00)$ & $11.85(0.00)$ \\
\hline & India $_{\text {Model I }}$ & $1363.65(0.00)$ & $14.71(0.00)$ & $12.50(0.00)$ \\
\hline & India $_{\text {Model II }}$ & $1228.82(0.00)$ & $10.04(0.00)$ & $8.92(0.00)$ \\
\hline & India $_{\text {Model III }}$ & $1429.70(0.00)$ & $12.63(0.00)$ & $10.87(0.00)$ \\
\hline & China $_{\text {Model I }}$ & $1505.63(0.00)$ & $13.53(0.00)$ & $11.26(0.00)$ \\
\hline & China $_{\text {Model II }}$ & $1429.11(0.00)$ & $11.53(0.00)$ & $9.48(0.00)$ \\
\hline & China $_{\text {Model III }}$ & $1223.03(0.00)$ & $11.94(0.00)$ & $10.46(0.00)$ \\
\hline & South Africa $_{\text {Model I }}$ & $1505.33(0.00)$ & $14.39(0.00)$ & $12.04(0.00)$ \\
\hline & South Africa $_{\text {Model II }}$ & $1223.26(0.00)$ & $13.59(0.00)$ & $12.71(0.00)$ \\
\hline & South Africa ${ }_{\text {Model III }}$ & $1490.18(0.00)$ & $10.61(0.00)$ & $9.70(0.00)$ \\
\hline
\end{tabular}


(continued)

\begin{tabular}{|c|c|c|c|c|}
\hline \multicolumn{2}{|c|}{ TMAN-Gravity model } & $\begin{array}{c}\text { Breusch- } \\
\text { Pagan LM }\end{array}$ & $\begin{array}{c}\text { Pesaran } \\
\text { Scaled LM }\end{array}$ & Pesaran CD \\
\hline \multirow{15}{*}{$\begin{array}{c}\text { The Eastern } \\
\text { European } \\
\text { group }\end{array}$} & Brazil $_{\text {Model I }}$ & $1404.96(0.00)$ & $15.36(0.00)$ & $14.92(0.00)$ \\
\hline & Brazil $_{\text {Model II }}$ & $1284.04(0.00)$ & $16.74(0.00)$ & $13.11(0.00)$ \\
\hline & Brazil $_{\text {Model III }}$ & $1566.52(0.00)$ & $9.63(0.00)$ & $7.13(0.00)$ \\
\hline & Russia $_{\text {Model I }}$ & $1601.12(0.00)$ & $15.39(0.00)$ & $12.11(0.00)$ \\
\hline & Russia $_{\text {Model II }}$ & $1592.07(0.00)$ & $14.43(0.00)$ & $13.97(0.00)$ \\
\hline & Russia $_{\text {Model III }}$ & $1552.48(0.00)$ & $14.66(0.00)$ & $12.70(0.00)$ \\
\hline & India $_{\text {Model I }}$ & $1263.11(0.00)$ & $10.19(0.00)$ & $8.72(0.00)$ \\
\hline & India $_{\text {Model II }}$ & $1408.28(0.00)$ & $12.51(0.00)$ & $11.84(0.00)$ \\
\hline & India $_{\text {Model III }}$ & $1148.63(0.00)$ & $13.74(0.00)$ & $12.24(0.00)$ \\
\hline & China $_{\text {Model I }}$ & $1477.36(0.00)$ & $11.09(0.00)$ & $9.33(0.00)$ \\
\hline & China $_{\text {Model II }}$ & $1529.00(0.00)$ & $13.42(0.00)$ & $12.04(0.00)$ \\
\hline & China $_{\text {Model III }}$ & $1365.12(0.00)$ & $15.42(0.00)$ & $14.68(0.00)$ \\
\hline & South Africa ${ }_{\text {Model I }}$ & $1420.42(0.00)$ & $12.50(0.00)$ & $11.48(0.00)$ \\
\hline & South Africa ${ }_{\text {Model II }}$ & $1377.62(0.00)$ & $11.29(0.00)$ & $10.91(0.00)$ \\
\hline & South Africa ${ }_{\text {Model III }}$ & $1200.02(0.00)$ & $9.38(0.00)$ & $7.90(0.00)$ \\
\hline \multirow{15}{*}{$\begin{array}{c}\text { The Latin } \\
\text { American and } \\
\text { Caribbean } \\
\text { group }\end{array}$} & Brazil $_{\text {Model I }}$ & $1572.01(0.00)$ & $14.64(0.00)$ & $12.88(0.00)$ \\
\hline & Brazil $_{\text {Model II }}$ & $1103.44(0.00)$ & $12.42(0.00)$ & $11.21(0.00)$ \\
\hline & Brazil $_{\text {Model III }}$ & $1292.01(0.00)$ & $11.29(0.00)$ & $10.84(0.00)$ \\
\hline & Russia $_{\text {Model I }}$ & $1472.83(0.00)$ & $9.16(0.00)$ & $8.83(0.00)$ \\
\hline & Russia $_{\text {Model II }}$ & $1355.33(0.00)$ & $14.29(0.00)$ & $12.10(0.00)$ \\
\hline & Russia $_{\text {Model III }}$ & $1291.08(0.00)$ & $11.15(0.00)$ & $10.54(0.00)$ \\
\hline & India $_{\text {Model I }}$ & $1420.01(0.00)$ & $13.80(0.00)$ & $12.66(0.00)$ \\
\hline & India $_{\text {Model II }}$ & $1290.42(0.00)$ & $10.38(0.00)$ & $9.92(0.00)$ \\
\hline & India $_{\text {Model III }}$ & $1232.11(0.00)$ & $14.29(0.00)$ & $13.11(0.00)$ \\
\hline & China $_{\text {Model I }}$ & $1241.76(0.00)$ & $13.29(0.00)$ & $12.84(0.00)$ \\
\hline & China $_{\text {Model II }}$ & $1301.79(0.00)$ & $11.27(0.00)$ & $9.28(0.00)$ \\
\hline & China $_{\text {Model III }}$ & $1192.10(0.00)$ & $13.24(0.00)$ & $12.01(0.00)$ \\
\hline & South Africa ${ }_{\text {Model I }}$ & $1577.47(0.00)$ & $14.33(0.00)$ & $12.40(0.00)$ \\
\hline & South Africa ${ }_{\text {Model II }}$ & $1438.69(0.00)$ & $10.05(0.00)$ & $8.92(0.00)$ \\
\hline & South Africa $_{\text {Model III }}$ & $1180.00(0.00)$ & $12.42(0.00)$ & $10.15(0.00)$ \\
\hline \multirow{7}{*}{$\begin{array}{l}\text { The Western } \\
\text { European and } \\
\text { others group }\end{array}$} & Brazil $_{\text {Model I }}$ & $14.91(0.00)$ & $13.20(0.00)$ & $11.31(0.00)$ \\
\hline & Brazil $_{\text {Model II }}$ & $1273.08(0.00)$ & $14.11(0.00)$ & $12.95(0.00)$ \\
\hline & Brazil $_{\text {Model III }}$ & $1390.41(0.00)$ & $10.75(0.00)$ & $9.18(0.00)$ \\
\hline & Russia $_{\text {Model I }}$ & $1352.03(0.00)$ & $14.20(0.00)$ & $13.77(0.00)$ \\
\hline & Russia $_{\text {Model II }}$ & $1128.15(0.00)$ & $9.29(0.00)$ & $8.85(0.00)$ \\
\hline & Russia $_{\text {Model III }}$ & $1409.88(0.00)$ & $13.83(0.00)$ & $12.15(0.00)$ \\
\hline & India $_{\text {Model I }}$ & $1266.31(0.00)$ & $12.55(0.00)$ & $10.63(0.00)$ \\
\hline
\end{tabular}


(continued)

\begin{tabular}{|c|c|c|c|c|}
\hline \multicolumn{2}{|c|}{ TMAN-Gravity model } & $\begin{array}{c}\text { Breusch- } \\
\text { Pagan LM }\end{array}$ & $\begin{array}{c}\text { Pesaran } \\
\text { Scaled LM }\end{array}$ & Pesaran CD \\
\hline \multirow{4}{*}{$\begin{array}{c}\text { The Western } \\
\text { European and }\end{array}$} & India $_{\text {Model II }}$ & $1279.52(0.00)$ & $14.18(0.00)$ & $13.50(0.00)$ \\
\cline { 2 - 5 } others group & India $_{\text {Model III }}$ & $1477.59(0.00)$ & $10.53(0.00)$ & $9.06(0.00)$ \\
\cline { 2 - 5 } & China $_{\text {Model I }}$ & $1129.62(0.00)$ & $13.18(0.00)$ & $10.93(0.00)$ \\
\cline { 2 - 5 } & China $_{\text {Model II }}$ & $1204.00(0.00)$ & $14.91(0.00)$ & $13.04(0.00)$ \\
\cline { 2 - 5 } & China $_{\text {Model III }}$ & $1238.11(0.00)$ & $10.44(0.00)$ & $8.77(0.00)$ \\
\cline { 2 - 5 } & South Africa $_{\text {Model I }}$ & $1471.57(0.00)$ & $12.82(0.00)$ & $10.26(0.00)$ \\
\cline { 2 - 5 } & South Africa $_{\text {Model II }}$ & $1266.70(0.00)$ & $11.29(0.00)$ & $10.01(0.00)$ \\
\cline { 2 - 5 } & South Africa $_{\text {Model III }}$ & $1277.04(0.00)$ & $13.53(0.00)$ & $12.26(0.00)$ \\
\hline
\end{tabular}

(Source) Authors' compilation from Eviews 9.0; LM = Lagrange Multiplier; CD = Cross-sectional Dependence 